\title{
Validation of an application for forecasting blowing snow
}

\author{
Gilbert Guyomarc'h, Laurent Mérindol \\ Centre d'Études de la Neige, Centre National de Recherches Météorologiques, Météo-France, 38406 Saint-Martin-d'Hères Cedex, France
}

\begin{abstract}
Wind effects on snow distribution and increasing avalanche hazard are well known. Forecasting such phenomena is based on empirical rules and experience. For two years, the CEN has tested a new analysis program for forecasting blowing-snow events at an Alpine site. The aim is to improve avalanche-forecasting tools so as to increase the accuracy of avalanche-hazard forecasts. Our understanding of blowing-snow mechanisms began with observations and field measurements at a high altitude site during periods of strong wind. Using an empirical approach, snow-grain morphology, cohesion between snow particles and grain-size have been combined to define a function for the calculation of a "driftability index". By comparing this index with the wind thresholds observed in field, a snowdrifting index has been defined. Snow profiles calculated by $S A$ FRAN (estimation of relevant meteorological parameters for snow models) and Crocus (snowpack-evolution model) were analysed using an application called PROTEON. Forecasts of wind velocity and snow profiles have been used to discriminate between periods with or without snow transport. For the subsequent 24 hours and for each snow layer, the value of this snowdrifting index is calculated and displayed on a graph. Validation consists of a comparison of forecasted blowing-snow periods with the field observations and measurements at a pass situated at $2700 \mathrm{~m}$ a.s.l. Meteorological and snow-parameter data are available at this site.
\end{abstract}

\section{INTRODUGTION}

The effect of wind on weakening the structure of snow crystals begins during snowfall. When the snow flakes reach the snow surface, they begin to move as soon as the wind velocity reaches a threshold that depends on the snow type. The snow grains quickly fragment and their size decreases as they collide with each other or with the ground. When snow drifts in dry air, sublimation can very efficiently reduce the grain-size. As their size decreases, the suspended particles tend to bond quickly by a sintering action. This explains the rapid formation of cornices and could be at the origin of slab-avalanche release (Meister, 1989)

Many studies have been conducted on blowing snow. The subject of these studies has been based essentially on a theoretical approach to blowing-snow effects. For example, several papers related to this theme have been published: physical model (Pomeroy, 1989), theoretical development of the saturation notion (Takeuchi, 1980), investigation of threshold wind speeds (Schmidt, 1981; Takeuchi and others, 1990), or geographical deposition (Föhn, 1980).

For 5 years the Centre d'Études de la Neige (CEN) has investigated blowing snow. The aim of this research, among other things, has been to understand the relationship between blowing snow and avalanche activity. The final goal is to introduce the results of this research into snowpack-evolution models and to develop an application that forecasts blowing-snow events.

Blowing snow is one of the most important factors for forecasting the accidentally release of avalanches. The effect of blowing snow is not always easily quantified and most forecasting methods are based only on empirical rules and org/10.3189/1998AoG26-1-138-143 Published online by Cambridge University Press experience. From this study, we aim to provide users (avalanche forecasters, snow-safety services, etc.) with snowdrifting diagnostic tools to better understand wind effects on the snowpack in mountain regions. A special aspect of this study was taking into account wind-speed thresholds, according to morphological snow-grain parameters, in order to improve the 24 hour forecast of avalanche hazards.

\section{RESEARCH METHODS}

\section{Experimental site}

A large, north-south oriented pass (Col du Lac Blanc, $2700 \mathrm{~m}$ a.s.1.), where the wind is generally similarly channelled, was chosen for this research program. Close by (at Dôme des Petites Rousses), avalanche activity on two eastfacing slopes has been followed and observed: on one slope, avalanches are artificially released according to the snowcover conditions; on the other slope, there has been completely natural avalanche activity (Guyomarc'h and others, 1992).

\section{Instrumentation}

Several parameters (air temperature, wind direction and velocity, snow depth, snow cover, surface temperature and water equivalent of precipitation) are recorded hourly by a sheltered computer and transmitted to Grenoble on request. For 4 years, we have complemented these measurements with data from another automatic meteorological station at the top of the Dôme des Petites Rousses (2800 m).

In addition to these instruments, a new device has been 
developed and tested. This apparatus is based on a set of snow-depth sensors set up on two cables along a slope; it has been called a "snow profiler" (Guyomarc'h and others, 1997). It follows the real-time snow-depth evolution and obtains, every 15 minutes, a snow profile along a slope at a site subject to snowdrifting.

\section{Field measurements}

Our goal is to measure precisely the different wind-velocity thresholds allowing for snow transport and relate these to the morphological and physical features of the snow particles. As often as possible, the automatic measurements have been supplemented with manual observations in order to describe, in maximum detail, each period of snowdrifting. The following observations were carried out:

Before snowfalls or strong wind conditions, snowpack observations (type of snow, density, temperature profile, shear strength, surface conditions, etc.) were made in the uppermost meter of the snowpack.

During snow storms or snowdrifting periods, drift-flux measurements and vertical profiles of the wind speed were made (Castelle, 1994).

After these periods, complete snow pits were once again made. If a slab avalanche had been released, snow-profile observations were made on the failure and the slab stratigraphy studied.

Several samples of snow grains were collected during the previous stages and transported to a cold laboratory for later microscopic analysis. Pictures of grains have been recorded on video tape and the characteristics of winddrift snow particles have then been determined. These observations have been very useful for associating snow-morphology parameters with wind velocity.
PROTÉON: AN APPLICATION FOR FORECASTING BLOWING SNOW

\section{A snowdrifting-event forecasting model}

In order to determine the risk of slab avalanche release, avalanche forecasters have to evaluate, among a number of other parameters, the wind effects on the snow distribution and on the snow pack stability. One problem is to know whether snowdrifting occurs in a particular site. Using results from field measurements, a model called PROTEON (PRévision de l'Occurrence de Transport ÉOlien de la Neige - forecasting of wind snowdrifting occurrence) has been developed (Guyomarc'h and Mérindol, 1995). The method, presented below, consists of :

Estimation of the wind velocity at the site using a statistical method,

Simulation of the snow-particle type at the snowpack surface and an estimation of its driftability,

Calculation of a "snowdrifting index".

\section{Wind speed and direction estimation}

The first part of the application was developed to estimate wind velocity and direction at Col du Lac Blanc. For this, data from the European Centre for Medium-Range Weather Forecasts were used. The statistical relationships between the model parameters on a $3 \times 3$ grid (covering the north of the French Alps) and wind measurements at the site have been searched for. $A$ multi-linear-regression method was used to calculate equations for the daily estimation of wind direction and velocity.

A comparison between measured wind parameters (over the 1993-94 season but not included in the learning file) and the forecast from this method is shown in Figure 1.
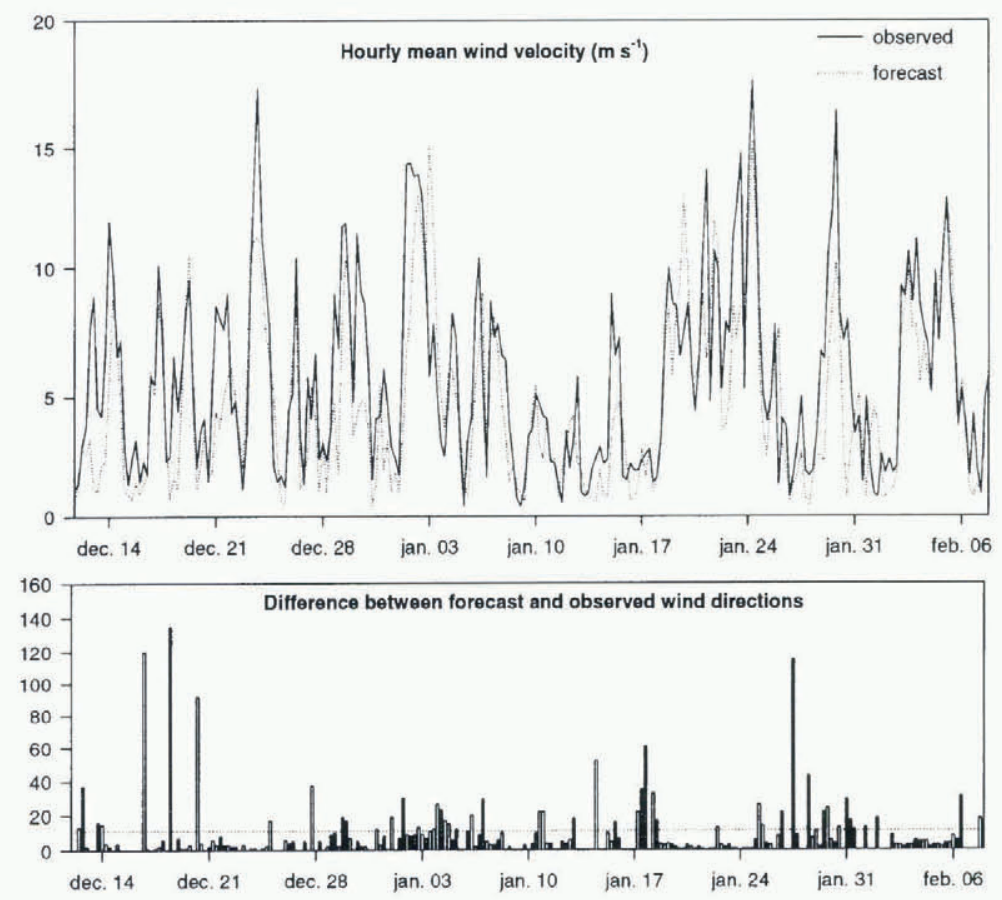

Fig. 1. Comparison between the measured wind velocity (continuous line) and the analysed one (dotted line) at Col du Lac Blanc. The graph shows the absolute value of the difference between forecast and observed wind direction (dotted line represents the mean). 
In most cases, wind velocity is well estimated (correlation coefficient $R=0.77$ ). The highest difference in wind direction appears only with low velocity (less than the threshold of the start of snowdrifting); in the other cases, the forecast direction is quite correct.

\section{Snow-particle mobility}

To reach our objective, it was necessary to know precisely the daily state of the snowpack surface. For this, SAFRAN (Durand and others, 1993) - Crocus (Brun and others, 1992) was used to simulate the evolution of the snowpack at the experimental site. The first model $(S A F R A N)$ provides the second one (Crocus) with an estimate of relevant meteorological parameters (such as air temperature, wind velocity, humidity, precipitation and its phase, etc.). Then, Crocus calculates a detailed stratigraphy of the snow cover for the site considered. One of the most important problems is having a good description of snow-grain characteristics, so a modification of the formalism used (as described by Colbeck and others, 1990) has been necessary in order to describe snow evolution as a function of continuous parameters (Fig. 2). These variables are dendricity, sphericity and grain-size. Dendricity varies from 1 to 0 , according to the part of the original crystal shape still remaining in a snow layer. Sphericity varies from 0 to 1 and describes the ratio of rounded vs angular shapes.

Using an empirical approach, we combined grain morphology, and grain-size to define a function describing a "driftability index". This approach allowed us to take into

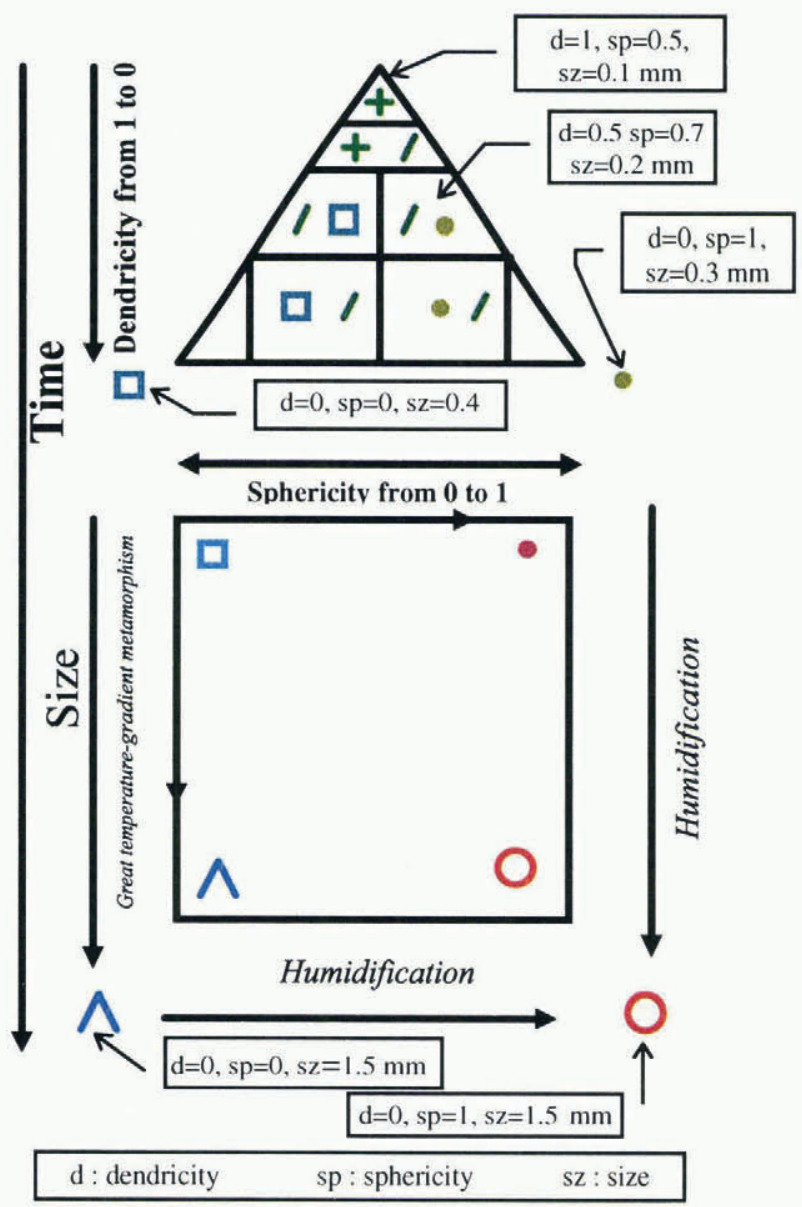

Fig. 2. Snow-grain symbolism in Crocus ( as a function of continuous parameters). account indirectly the differences in cohesion between snow particles, notably the sintering process. The influence of temperature on the snow cover is also indirectly taken into account through the metamorphism laws used by Crocus. For example, it considers that, with the same dendricity, faceted crystals can be eroded more easily than small rounded grains, because of their sphericity difference. This hypothesis was confirmed by our field measurements.

In PROTÉON's analysis, a Crocus-simulated snowpack was analysed from the top. For each layer, the driftability index $(d i)$ was calculated. For each type of snow particle, it was necessary to describe the snow using the same parameters as the Crocus model. The analysis was separated into two cases:

The first case was when fresh snow was still present in a layer (that is its dendricity was $>0$ ). In this case, the possibility of snow transport depends essentially on sintering cohesion between snow grains. It is described using the following function:

$$
d i=0.75 \times d-0.5 \times s+0.5
$$

where $d$ is dendricity $(1-0)$ and $s$ is sphericity $(0-1)$.

The second case was when the grain type was only the result of snow metamorphism and its possibility of being transported by wind depended upon its size and sphericity. In this case, we used the function:

$$
d i=0.583 \times g s-0.833 \times s+0.833
$$

where $g s$ is the grain-size and $s$ is sphericity $(0-1)$

We decided that a crust layer $>3 \mathrm{~mm}$ or a wet layer prevented snowdrifting and consequently stops the analysis. The driftability index takes a value between 1 for fresh recent snow fallen without wind and -1 for spherical melted snow.

\section{Snow-driftability index}

The last stage of the study consisted of a combination of previous information ( $d i$ and wind velocity) in order to forecast the occurrence of snow 1day in advance in 6 hourly timesteps. Using field measurements and observations over 4 years, we determined, for each type of snow, the windvelocity threshold which allowed snowdrifting. We compared at 6 hourly time-steps, the driftability-index value with the forecasted wind velocity. Then, it was possible to define a function using this index and wind velocity which

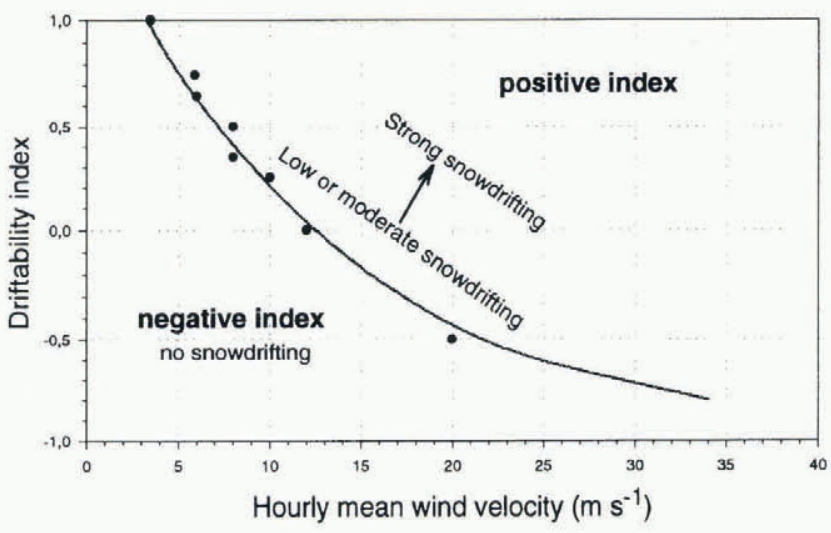

Fig. 3. The two domains of the snowdrifting index values. 


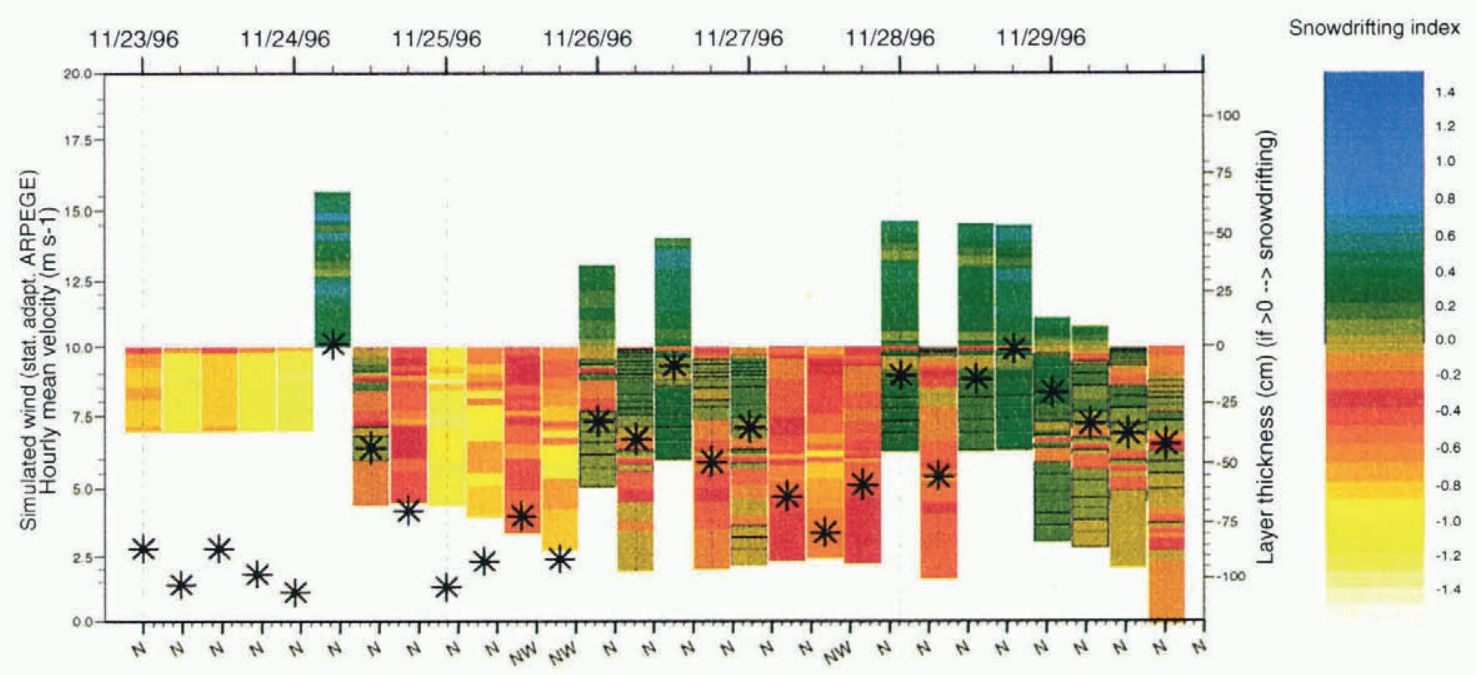

Fig. 4. Evolution of the profile analysed by PROTEONat the site from 23-30 November 1996. The y axis gives the snow depth that could be eroded by wind. The green and blue colours describe a positive snowdrifting index for each snow layer (snowdrifting should occur ). Yellow and red colours describe a negative snowdrifling index for snow layers which cannot be eroded by the forecast wind velocity. These layers are drawn below the zero line.

discriminated between no-transport cases and the others. We calculate the driftability index $(s i)$ as:

$$
s i=-2.868(\exp (-0.085 w))+1+d i
$$

where $w$ is wind velocity and $d i$ is the previous snow-driftability index.

If the value of this function is positive, it is considered that snowdrifting will occur at the site (Fig. 3) and the thickness of the wind-eroded layer can be calculated.

The evolution of the "driftability index" can be displayed on a graph for the previous 7 days. This information is available to an avalanche forecaster on his computer screen (Fig. 4).

\section{TEST AND VALIDATION}

\section{Test on a whole season}

For validating this forecasting tool, a simulation of the whole 1992-93 winter season was made. The snowdrifting index was calculated at 6 hourly time-steps, using the measured wind velocity. Then, it was compared with snowdrift-

\begin{tabular}{|c|c|c|}
\hline $\begin{array}{r}\text { Forecast } \\
\text { events }\end{array}$ & $\begin{array}{r}\text { Without } \\
\text { snowdrifting }\end{array}$ & Snowdrifting \\
\hline $\begin{array}{c}\text { Observed } \\
\text { events }\end{array}$ & $75.7 \%$ & $14 \%$ \\
\hline $\begin{array}{c}\text { Without } \\
\text { snowdrifting }\end{array}$ & $2.3 \%$ & $8 \%$ \\
\hline Snowdrifting & $2.3 \%$ \\
\hline
\end{tabular}

Fig. 5. Comparison between observed snow events and simulated ones (PROTEON) for 776 periods of the 1992-93 winter season ing periods at Col du Lac Blanc. The lack of a reliable sensor specific to the detection of snowdrifting in real-time led us to use the difference between the hourly maximum and minimum values of the depth sensor. When snowdrifting occurs, the snow particles in motion cause interference, near the snowpack surface, to the ultrasonic waves used by the snow-depth sensor. So, when this difference (averaged over an interval of 6 hours) increases above $2 \mathrm{~cm}$, it is assumed that a snowdrifting event occurred at the site (snowfall is easily distinguished using records from the heating precipitation gauge).

The results from this comparison (made every 6 hours 776 times) are shown in Figure 5.

During this period, about $80 \%$ of the snowdrifting events were detected. These periods represent only $10.3 \%$ of the time during the winter season; $14 \%$ of the time false positive predictions were made.

\section{Focus on a period of the 1996-97 season}

The beginning of the 1996-97 season was rich in snowdrifting events. During this period, a new snow accumulation of about $2 \mathrm{~m}$ was observed at Col du Lac Blanc. In order to achieve a qualitative validation, a graphical comparison was made as a first approach. For this, it was necessary to display two indices: the first one synthesized the information of the analysed profile calculated by PROTEON and the second one summarised the temporal behaviour of the snowpack thickness between two time-steps (6 hours). By using the SAFRAN-Crocus simulation (four times a day) and the PROTEON analysis, a compound index (indc) was calculated for each simulated snow profile (Fig. 6). The principle is the following:

$$
i n d c=\frac{\sum_{i=1}^{n} i n d_{i} \times e p_{i}}{\sum_{i=1}^{n} e p_{i}}
$$

where $n$ is the number of driftable layers, $i n d_{i}$ is the snowdrifting index of the layer $i, e p_{i}$ is thickness of the layer $i$.

To define the snowdrifting period, hourly data from Col 


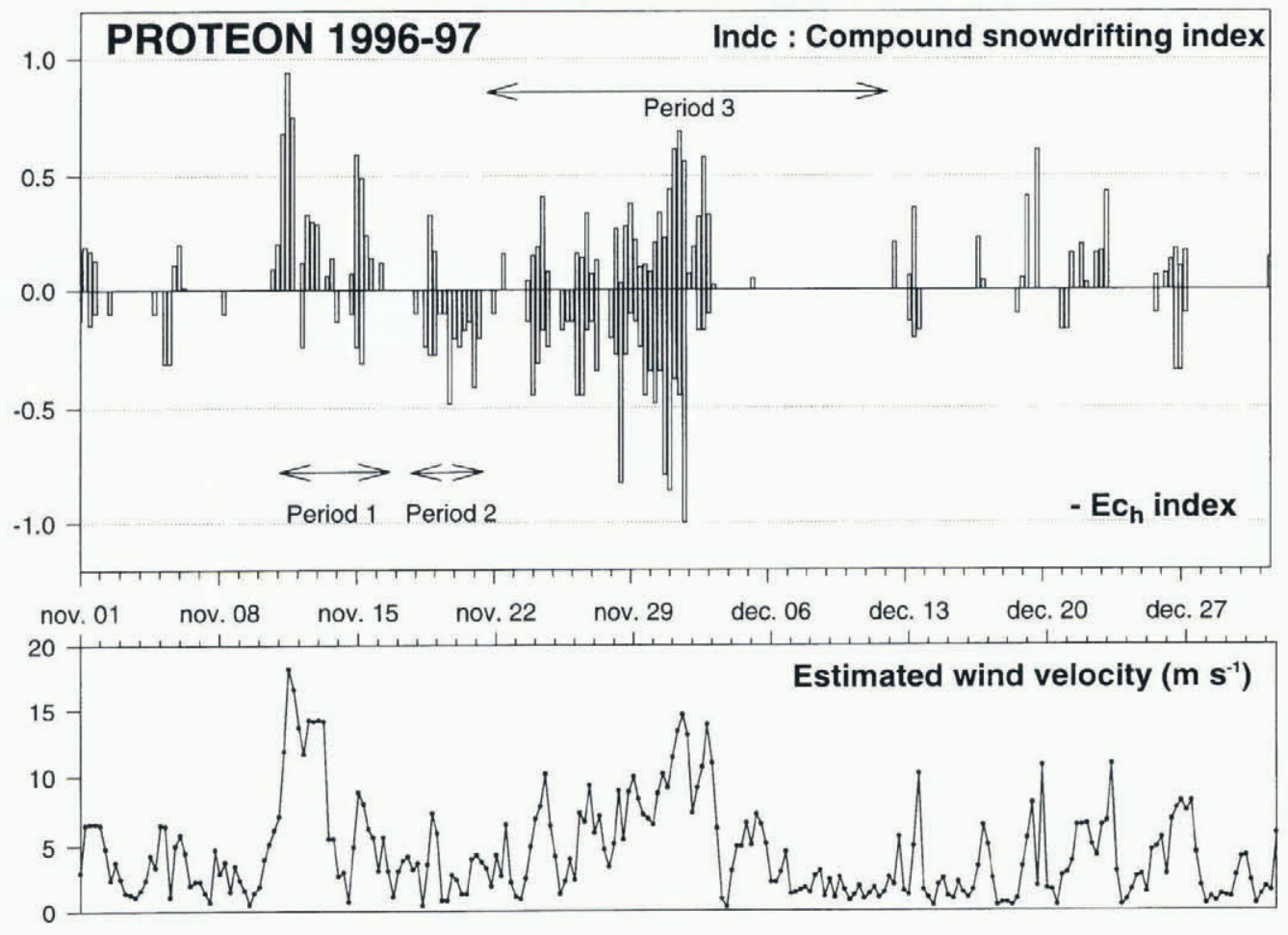

Fig. 6. Comparison between the compound index and the $E C_{h}$ index.

du Lac Blanc were used. In order to optimise the available data, the following function $\left(E c_{h}\right)$, named the normalized difference, has been defined:

$$
E c_{h}=\frac{\max \left(\left[\left(\max _{t=h-3}^{h+3}\left(h t n m x_{t}-h \text { tnm } n_{t}\right)\right)-2\right], 0\right)}{\text { diffm } x-2}
$$

where diff $m x$ is the maximum difference for the period, htnmx is the hourly maximum of snow depth, htnmn is the hourly minimum of snow depth. By definition, the $E c_{h}$ index is in the range $(0,1)$.

A first validation could be made by comparing the values of the two previous indices on a graph. Figure 6 shows that, taken as a whole, the compound index and the normalized difference are in phase.

If we focus our attention on period 1 , it appears that, when the driftable snow is thin, these layers disappear quickly due to the efficiency of wind erosion. However, the Crocus model is not yet able to remove snow layers, so snowdrifting conditions are still forecast by PROTEON.

In period 2, another kind of disagreement is shown between $E c_{h}$ and the results of the PROTEON analysis. This is explained by underestimation of the forecast wind velocity (the hourly mean of the measured wind velocity is $5 \mathrm{~m} \mathrm{~s}^{-1}$ stronger than the forecast one).

In period 3, a better agreement is observed. During these 20 days, snow depth increased by more than $150 \mathrm{~cm}$ and the wind blew with an average velocity greater than $10 \mathrm{~ms}^{-1}$. For these reasons, there was always an erodable snow layer.

The following contingency tables (Figs 7 and 8) show the comparison between observed snowdrifting events and the simulated ones for the same period. In calculating these tables, the information delivered by each index has been transformed to a simulated or an observed snowdrifting event when the index is positive. In the whole period, about $62 \%$ of the snowdrifting events have been well forecast. https://doi.org/10.3189/1998AoG26-1-138-143 Published online by Cambridge University Press

\begin{tabular}{|c|c|c|}
\hline $\begin{array}{r}\text { Forecast } \\
\text { events }\end{array}$ & $\begin{array}{r}\text { Without } \\
\text { snowdrifting } \\
\text { Observed } \\
\text { events }\end{array}$ & Snowdrifting \\
\hline $\begin{array}{c}\text { Without } \\
\text { snowdrifting }\end{array}$ & 137 & 38 \\
\hline Snowdrifting & 26 & 43 \\
\hline
\end{tabular}

Fig. 7. Test for the whole period (1 November - 31 December

\begin{tabular}{|c|c|c|}
\hline $\begin{array}{r}\text { Forecast } \\
\text { events }\end{array}$ & $\begin{array}{c}\text { Without } \\
\text { snowdrifting }\end{array}$ & Snowdrifting \\
\hline $\begin{array}{c}\text { Without } \\
\text { snowdrifting }\end{array}$ & 45 & 5 \\
\hline Snowdrifting & 4 & 28 \\
\hline
\end{tabular}

Fig. 8: Test for the reduced period (23 November - 12 December 1996).

These events represent $28.3 \%$ of the time during this period. But, $15.6 \%$ of the time (false alarm), snowdrifting was forecast when none occurred. In period 3, about $87 \%$ of the snowdrifting events were detected. These events represent $39 \%$ of the time. In this period, only $6.1 \%$ of the time was the forecast false positive. 


\section{CONCLUSION}

This paper has shown it is feasible to forecast snowdrifting events 1 day in advance with satisfactory accuracy. This application is integrated into the SAFRAN-Crocus-MÉPRA (Giraud and others, 1994) operational chain for experimental testing in practical conditions and has been used by avalanche-risk forecasters from Grenoble for the last two winter seasons. The information can be transmitted, on request, to the Snow Safety Service of Alpe d'Huez.

These results can be improved. When the same snowsurface conditions remain more than 12 or 24 hours, the same thickness of transported snow will be forecast for each 6 hour step. By using measurements from the snow profiler, we plan to determine the rates and the time needed to erode a snow layer according to the snow-surface state and wind velocity. The first results have been published (Guyomarc'h and others, 1997). Then, the erosion or accumulation of blowing snow must be taken into account in the Crocus simulation.

Although this application can improve avalanche-hazard forecasting in some conditions, it is important to bear in mind that this tool has been designed for forecasters, which means the results must fit thier expectations, and this is not always measurable in terms of correlation coefficients and contingency tables.

\section{ACKNOWLEDGEMENTS}

This program has been supported financially by the Région Rhone-Alpes and the French government. Logistic support from SATA (the Snow Safety Service of Alpe d'Huez) made this study possible and is gratefully acknowledged. This research is part of the European Research Program called SAME (Snow Avalanche Warning and Mapping in Europe), which is supported financially by the European Commission in the field of the "Environment and Climate" program.

\section{REFERENCES}

Brun, E., P. David, M. Sudul and G. Brunot. 1992. A numerical model to simulate snow-cover stratigraphy for operational avalanche forecasting. 7. Glaciol., $38(128), 13-22$.

Castelle, T. 1995. Transport de la neige par le vent en montagne: approche expérimentale du site du Col du Lac Blanc. (Thèse de doctorat, École Polytechnique Fédérale de Lausanne.

Colbeck, S. C. and 7 others. 1990. The international classification for seasonal snow on the ground. Wallingford, Oxon, International Association of Scientific Hydrology: International Commission on Snow and Ice.

Durand, Y., E. Brun, L. Mérindol, G. Guyomarc'h, B. Lesaffre and E. Martin. 1993. A meteorological estimation of relevant parameters for snow models. Ann. Glaciol., 18, 65-71.

Föhn, P. M. B. 1980. Snow transport over mountain crests. f. Glaciol., 26 94, $469-480$.

Giraud, G., E. Brun, Y. Durand and E. Martin. 1994. Validation of objective models to simulate snow cover stratigraphy and avalanche risks. In ISSW*97. International Snow Science Workshop, 30 October - 3. November 1.99t. Snowbird, Utah. Proceedings. Snowbird, UT, P.O. Box 49, 509-517.

Guyomarc'h, G. and T. Castelle. 1993. A study of wind drift phenomena on an alpine site. In Armstrong, R., ed. ISSW 92. A Merging of Theory and Practice. International Snow Science Workshop, 18 October 1992. Breckenridge. Colorado. Proceedings. Denver, CO, Avalanche Information Center, 57-67.

Guvomarc'h. G. and I. Mérindol. 1995. PROTEON-Vers une prévision locale du transport de neige par le vent. In Sivardière, F., ed. Les apports de la recherche scientifique à la sécurité neige, glace et avalanche. Actes de Colloque, Chamonix 30 mai - 3 juin 1995. Grenoble, Association Nationale pour l'Étude de la Neige et des Avalanches (ANENA), 97-102.

Guyomarc'h, G., L. Mérindol and M. Sudul. 1997. Test of a multiplex snow depth sensor along a slope. In ISSW'96. International Snow Science Workshop, 6-10 October 1996, Banff, Alberta. Proceedings. Revelstoke, B.C., Canadian Avalanche Association, 173-178.

Meister, R. 1989. Influence of strong winds on snow distribution and avalanche activity. Ann. Glaciol., 13, 195-201.

Pomeroy, J.W. 1989. A process-based model of snow drifting. Ann. Glaciol. $13,237-240$.

Schmidt, R. A. 1981. Estimates of threshold windspeed from particle sizes in blowing snow. Cold Reg. Sci. Technol., 4 (3), 187-193.

Takeuchi, M. 1980. Vertical profile and horizontal increase of drift-snow transport. J. Glaciol., $26(94), 481-492$

Takeuchi, M., K. Ishimoto and Y. Kajiya. 1990. Blowing snow problems and their countermeasures in Hokkaido, Japan. In Eighth PIARC International IVinter Road Congress. Proceedings. Vol. II. Sapporo, Japan, Hokkaido Development Bureau. Civil Engineering Research Institute, 249261. 